\title{
Increased Renal Thromboxane Production in Murine Lupus Nephritis
}

Vicki E. Kelley, Sarah Sneve, and Scott Musinski

Laboratory of Immunogenetics and Transplantation, Department of Medicine,

Brigham and Women's Hospital, Boston, Massachusetts 02115

\begin{abstract}
To determine whether the amount of cyclooxygenase metabolites correlates with the development of lupus nephritis, intrarenal eicosanoid production was measured in autoimmune mice. Disease progression was related to the renal biosynthesis of prostaglandin ( $\mathrm{PGE}_{2}$ ), prostacyclin (6 keto $\mathrm{PGF}_{1 \alpha}$ ), and thromboxane $\left(\mathrm{TXB}_{2}\right)$ using the MRL-lpr and NZB $\times$ NZW F1 hybrid mouse strains with predictably progressive forms of renal disease that mimic the human illness. Mice were evaluated for renal disease by measuring urinary protein excretion and renal immunopathological conditions and these features were related to renal eicosanoid production. These studies show that: $(a)$ intrarenal synthesis of TXB $_{2}$ increased incrementally in MRL-lpr and NZB $\times N Z W$ F1 hybrid mice as renal function deteriorated and renal pathologic events progressed; (b) there were no consistent increases in the levels of two other cyclooxygenase metabolites, $\mathrm{PGE}_{2}$ or 6 keto $\mathrm{PGF}_{1 \alpha}$; (c) increased $\mathrm{TXB}_{2}$ production occurred in the renal medulla, cortex, and within enriched preparations of cortical glomeruli; $(d)$ when renal disease was prevented by pharmacologic doses of $\mathrm{PGE}_{2}$, intrarenal $\mathrm{TXB}_{2}$ did not increase; (e) administration of a dose of ibuprofen $(9 \mathrm{mg} / \mathrm{kg})$, a cyclooxygenase inhibitor capable of reducing $90 \%$ of platelet $\mathbf{T X B}_{2}$ without affecting intrarenal levels, did not retard the progression of renal damage. Taken together, these data indicate that the intrarenal level of $\mathbf{T X B}_{2}$ rises in relation to the severity of murine lupus nephritis. Furthermore, because of the potential deleterious effects of $\mathrm{TXA}_{2}$, enhanced production of this eicosanoid may be an important mediator of renal injury.
\end{abstract}

\section{Introduction}

Autoimmune lupus mice are uniquely valuable for studies of chronic progressive renal injury because their disease is spontaneous and remarkably similar to the human condition. By using both the MRL/MP-lpr (MRL-lpr) ${ }^{1}$ and NZB $\times N Z W$ F1 hybrid $(N Z B \times W)$ mice with autoimmune lupus nephritis, it is possible to eliminate unimportant peculiar features unique to a strain and identify common denominators with potential pathogenic relevance.

Arachidonic acid metabolites, most notably prostaglandin

Received for publication 29 August 1984 and in revised form 24 September 1985.

1. Abbreviations used in this paper: $\mathrm{KRB}$, Krebs-Ringer buffer; MRL-

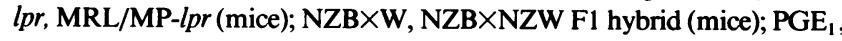
$\mathrm{PGE}_{2}$, and $\mathrm{PGF}_{2}$, prostaglandins $\mathrm{E}_{1}, \mathrm{E}_{2}$, and $\mathrm{F}_{2} ; 6$ keto $\mathrm{PGF}_{1 \alpha}$, prostacyclin; TXA ${ }_{2}$ and $\mathrm{TXB}_{2}$, thromboxanes $\mathrm{A}_{2}$ and $\mathrm{B}_{2}$.

J. Clin. Invest.

(c) The American Society for Clinical Investigation, Inc.

0021-9738/86/01/0252/08 $\$ 1.00$

Volume 77, January 1986, 252-259
$\mathrm{E}_{2}\left(\mathrm{PGE}_{2}\right)$, thromboxane $\mathrm{A}_{2}$ (TXA $)$, and prostacyclin (6 keto $\left.\mathrm{PGF}_{1 \alpha}\right)$, are potent mediators generated during immunologic inflammatory events and are capable of profoundly changing renal hemodynamics (reviewed in References 1-3). Recently, increased renal synthesis of thromboxane has been demonstrated during the inexorable progression of immune-mediated and nonimmunologic induced models of renal injury (4-8). Previous studies demonstrate that supplementing the diet of autoimmune mice with fish oil delays the onset of nephritis $(9,10)$, and that there is a concurrent reduction of endogenous renal cyclooxygenase metabolites during this dietary therapy (9). To assess whether this diet initiated a reduction in one or more renal cyclooxygenase products that might be related to the beneficial effect of a fish oil enriched diet, thromboxane $\mathrm{B}_{2}\left(\mathrm{TXB}_{2}\right), \mathrm{PGE}_{2}$, and 6 keto $\mathrm{PGF}_{1 \alpha}$, the stable hydrolysis product of prostacyclin, were measured from renal tissue of $\mathrm{NZB} \times \mathrm{W}$ and MRL-lpr mice, which share features of the renal disease, but which differ in their time course and immunologic disturbances $(11,12)$.

\section{Methods}

Mice. Male and female MRL-lpr as well as MRL/MP-+ (MRL-++) mice originally obtained from the Jackson Laboratory (Bar Harbor, ME) were bred in our own facility. Female and male MRL-lpr mice were used because disease expression is similar in both sexes. Mating of NZB and NZW in our laboratory produced NZB $\times W$ F1 hybrids. In that disease is more predictable and rapidly progressive in female $\mathrm{NZB} \times \mathrm{W}$ mice, studies were limited to this sex. All animals were kept under standard laboratory conditions.

Extraction of cyclooxygenase metabolites. Mice were killed by rapid cervical dislocation, kidneys were excised, and the capsule was gently removed. The kidney was then bisected and the medulla and cortex were rapidly separated by fine dissection. Tissues were immediately moistened with Krebs-Ringer bicarbonate buffer, $22.5 \mathrm{meq}$, containing $\mathrm{KCl}, \mathrm{NaCl}$, $\mathrm{NaHCO}_{3}, \mathrm{NaH}_{2} \mathrm{PO}_{4}$, and $\mathrm{CaCl}_{2}(\mathrm{KRB})$ at $\mathrm{pH} 7.2$, and $10-30 \mathrm{mg}$ of tissues were finely, uniformly minced with a razor blade and incubated in $2 \mathrm{ml}$ of $\mathrm{KRB}$ in a $25-\mathrm{ml}$ flask on a shaker platform in a $5 \% \mathrm{CO}_{2}$ incubator at $37^{\circ} \mathrm{C}$ for $15 \mathrm{~min}$ or $30 \mathrm{~min}$. All supernatants were immediately stored at $-20^{\circ} \mathrm{C}$ for $\mathrm{PGE}_{2}, 6$ keto $\mathrm{PGF}_{1 \alpha}$, and/or $\mathrm{TXB}_{2}$ analysis. It was not necessary to extract $\mathrm{PGE}_{2}, \mathrm{TXB}_{2}$, or 6 keto $\mathrm{PGF}_{1 \alpha}$ from tissues, because cyclooxygenase metabolites accumulate in the medium rather than in the tissues (13).

$P G E_{2}, T X B_{2}$, and 6 keto $P G F_{1 \alpha}$ assays. $\mathrm{PGE}_{2}, \mathrm{TXB}_{2}$, and 6 keto $\mathrm{PGF}_{1 \alpha}$ content in supernatant was determined by direct competitive binding radioimmunoassays. Anti-PGE ${ }_{2}$ serum, kindly provided by $\mathrm{Dr}$. Lawrence Levine (Brandeis University, Waltham, MA) has a $100 \%$ crossreactivity with $\mathrm{PGE}_{1}$ but only $2.7 \%$ with prostaglandin $\mathrm{F}_{2}\left(\mathrm{PGF}_{2}\right)$ and was used at a final dilution of 1:6,000. Therefore, our results cannot differentiate $\mathrm{PGE}_{1}$ and $\mathrm{PGE}_{2}$. However, because $\mathrm{PGE}_{2}$ was used as a standard, we have expressed our results as $\mathrm{PGE}_{2}$ equivalents. Antisera to $\mathrm{TXB}_{2}$, a generous gift of Dr. Perry V. Halushka (Medical University of South Carolina, Charleston, SC), did not cross-react $(0.04 \%)$ with other arachidonic acid metabolites and was used at a final dilution of 1:50,000 (14). 6 Keto PGF $_{1 \alpha}$ antisera was provided by Dr. Michael Dunn (Case Western Reserve Medical School, Cleveland, $\mathrm{OH}$ ) and has a crossreactivity as previously described and was used at a 1:15,000 dilution 
(15). All standards were provided by Dr. John Pike (The Upjohn Co., Kalamazoo, MI). $\left[{ }^{3} \mathrm{H}\right] \mathrm{PGE}_{2},\left[{ }^{3} \mathrm{H}\right] \mathrm{TXB}_{2}$, and $\left[{ }^{3} \mathrm{H}\right] 6$ keto $\mathrm{PGF}_{1 \alpha}$ were purchased from New England Nuclear (Boston, MA). Expressed values for $\mathrm{PGE}_{2}, \mathrm{TXB}_{2}$, and 6 keto $\mathrm{PGF}_{1 \alpha}$ represent the mean levels of duplicate determinations. The assay sensitivities for $\mathrm{TXB}_{2}, \mathrm{PGE}_{2}$, and 6 keto $\mathrm{PGF}_{1 \alpha}$ were $26,30-40$, and $30-40 \mathrm{pg} / \mathrm{ml}$, respectively. Intraassay coefficients of variations were $<2 \%$.

Urinary protein. 24-h urine specimens were collected by placing individual mice in metabolic cages as previously described (16). Proteinuria was quantitated by the trichloracetic acid method. Based on analysis of female Swiss Webster mice of 2-12 mo of age, urinary protein levels in excess of $1.2 \mathrm{mg} / 24 \mathrm{~h}$ were considered to be pathologic (17).

Renal morphology. Renal tissues were assessed for morphologic changes by light microscopy using coded slides. Kidney sections were fixed in alcoholic Bouin's fluid and stained with periodic acid-Schiff. Renal histopathologic alterations were graded using a semiquantitative scale ranging from 0 to 4.0 ( 0 , normal; 1 , a small increase of cells within the mesangium of the glomerulus; 2 , more pronounced increase in the number of mesangial cells and perivascular lymphocytic infiltration in the cortex and medulla; 3, lobular formation of the glomerulus, thickening of basement membrane, and prominent numbers of lymphocytes surrounding vessels; 4 , glomerular crescent formation, some sclerotic glomeruli, tubular atrophy, and casts and/or vasculitis).

Glomerular preparation. Glomerular enriched fractions were prepared by a modification of the method of Barcelli et al. (18). Kidneys were removed from mice and placed in phosphate-buffered saline (PBS) $(\mathrm{pH}$ 7.4) on ice. After bisecting each kidney, the capsule was removed and the cortex was separated from papilla and medulla. A total of 8-10 kidneys was pooled for each experiment. Cortical pieces were gently pressed through a $\# 200$ mesh stainless steel sieve ( $75-\mu \mathrm{m}$ pore diameter) into 10 $\mathrm{ml}$ of PBS. This suspension was forced through a 25 -gauge needle and then centrifuged at $1,500 \mathrm{rpm}$ for $5 \mathrm{~min}$ and the supernatant was discarded. The pellet was resuspended in $8 \mathrm{ml}$ of PBS and allowed to settle for $30 \mathrm{~min}$. Three quarters of the supernatant was aspirated and replaced with fresh PBS. This resuspension and settling step was repeated five to six times. The purity of glomerular preparations was assessed microscopically. Preparations consisted of $60-90 \%$ glomeruli with contamination consisting of tubular fragments. Glomerular enriched preparations were suspended in $2 \mathrm{ml}$ of $\mathrm{KRB}$ ( $\mathrm{pH} \mathrm{7.4)}$ ) at $37^{\circ} \mathrm{C}$ and incubated for 45 min in $12 \times 75-\mathrm{mm}$ siliconized glass tubes with constant agitation at $37^{\circ} \mathrm{C}$ in a $5 \% \mathrm{CO}_{2}$ environment. At the end of the incubation, glomeruli were centrifuged at $1,500 \mathrm{rpm}$ for $5 \mathrm{~min}$ and the supernatant was removed and stored at $-20^{\circ} \mathrm{C}$ for $\mathrm{PGE}_{2}$ and $\mathrm{TXB}_{2}$ analysis. Glomerular enriched pellets were resuspended in $2 \mathrm{ml}$ and stored at $-20^{\circ} \mathrm{C}$ until the total protein content was determined by the method of Lowry et al. (19).

In vivo treatments. Groups of MRL-lpr female mice ( 2 mo of age) were injected subcutaneously with $5 \mu \mathrm{g}$ of a stable $\mathrm{PGE}_{1}$ analogue, $15(\mathrm{~s})$ 15-methyl PGE 1 (a gift of Dr. John Pike, The Upjohn Co.), twice daily on 5 days of the week and once on Saturday and Sunday. Because previous studies indicated that injecting the vehicle control was similar to uninjected mice, our controls were not injected (16). Mice were treated for 2 mo and sacrificed at 4 mo of age.

Groups of MRL-lpr ( 2 mo of age) female and male and NZB $\times W$ ( 3 mo of age) female mice were injected daily for 1 wk with ibuprofen (generously supplied by The Upjohn Co.) $8-9 \mathrm{mg} / \mathrm{kg}$, diluted with PBS as previously described (20). Controls consisted of littermates receiving the vehicle alone.

Statistical analysis of data. The Student's $t$ test, Mann-Whitney U test, and linear regression analysis were used to determine significant differences in the data.

\section{Results}

\section{Cyclooxygenase metabolites in renal tissue}

$\mathrm{TXB}_{2}, P G E_{2}$, and 6 keto $P G F_{1 \alpha}$ in MRL-lpr mice. There was a dramatic increase in $\mathrm{TXB}_{2}$ levels in renal tissue of MRL-lpr mice during the course of autoimmune disease based on measurements before the onset of lymphadenopathy $(2 \mathrm{mo})$ and after palpable nodes were apparent (4-6 mo). A significant increase in $\mathrm{TXB}_{2}$ synthesis occurred in both the cortex and medulla of older MRL-lpr mice with lymphoproliferation as compared with MRL -++ and 2-mo MRL-lpr animals $(P<0.01$, Fig. 1$)$. Thus, the increase in $\mathrm{TXB}_{2}$ synthesis was limited to mice expressing products of the lpr gene. Cortical $\mathrm{TXB}_{2}$ levels in older MRL-lpr mice increased fivefold as compared to young mice of the same strain, whereas medullary $\mathrm{TXB}_{2}$ synthesis was at least three times greater in older MRL-lpr as compared with MRL- ++ and young MRL-lpr mice. In fact, cortical $\mathrm{TXB}_{2}$ ( $\mathrm{pg} / \mathrm{mg}$ of tissue) in MRL-lpr mice increased progressively$38 \pm 2,90 \pm 11,100 \pm 20$, and $326 \pm 37$ at $6,10,13$, and 20 wk of age, respectively. Similarly, medullary $\mathrm{TXB}_{2}(\mathrm{pg} / \mathrm{mg}$ of tissue) increased-90 $-2,165 \pm 3,280 \pm 10$, and $415 \pm 35$ at $6,10,13$, and $20 \mathrm{wk}$ of age, respectively. In striking contrast to the alteration in $\mathrm{TXB}_{2}$ synthesis in older MRL-lpr mice, $\mathrm{PGE}_{2}$ produc-
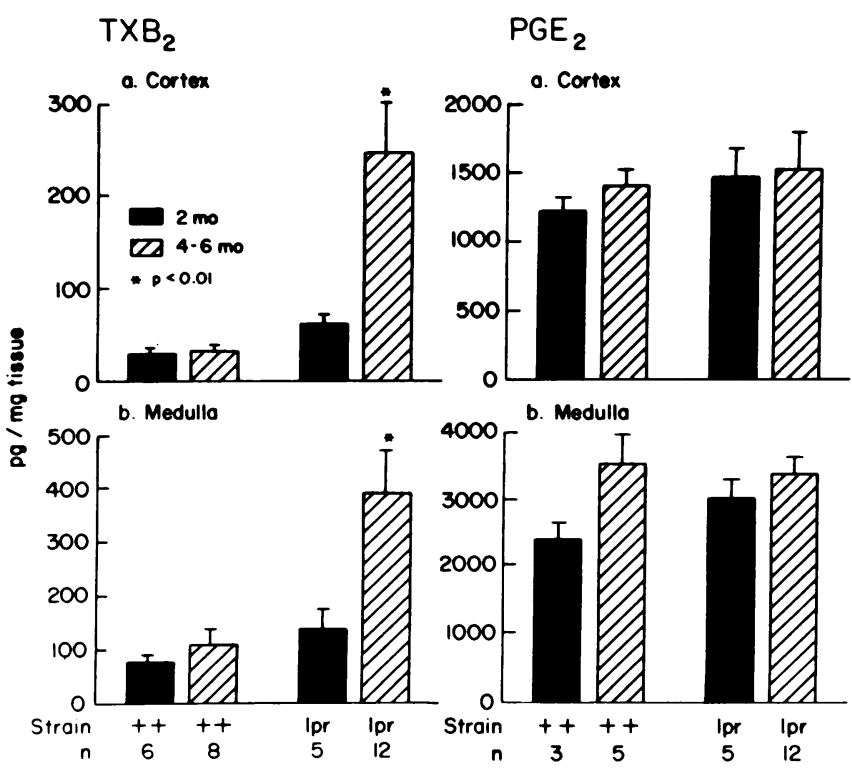

6-Keto PGF $1 a$

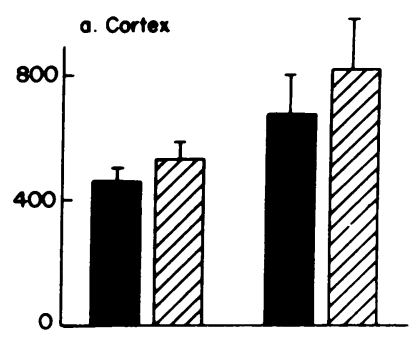

b. Medulla

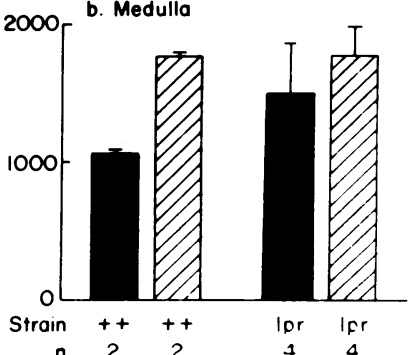

Figure 1. $\mathrm{TXB}_{2}, \mathrm{PGE}_{2}$, and 6 keto $\mathrm{PGF}_{1 \alpha}$ synthesis in renal tissue of MRL mice. $\mathrm{PGE}_{2}, 6$ keto $\mathrm{PGF}_{1 \alpha}$, and $\mathrm{TXB}_{2}(\mathrm{pg} / \mathrm{mg}$ of tissue) were determined by radioimmunoassay using renal cortex $(a)$ and medulla (b). Each bar represents the mean values \pm SEM. 

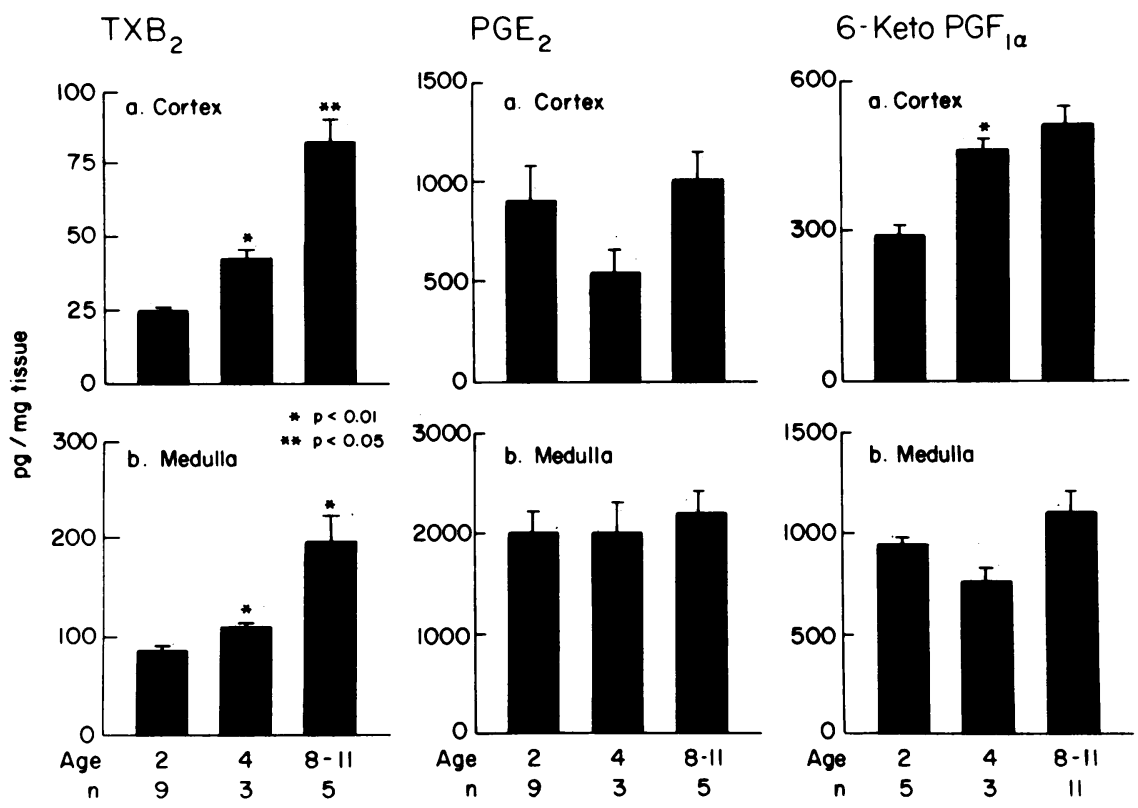

Figure 2. $\mathrm{TXB}_{2}, \mathrm{PGE}_{2}$, and 6 keto $\mathrm{PGF}_{1 \alpha}$ synthesis in renal tissues of NZB $\times W$ mice of 2,4 , and 8-11 mo of age. These eicosanoid measurements ( $\mathrm{pg} / \mathrm{mg}$ of tissue) were analyzed by radioimmunoassays. Mean renal cortex $(a)$ and medulla $(b)$ values are indicated by bars \pm SEM.

tion remained stable with increasing age for both the congenic strain and mice expressing the lpr gene (Fig. 1). When these renal tissues were further evaluated for their 6 keto PGF $_{1 \alpha}$ synthesis, the values for this eicosanoid were also similar in young and old MRL-lpr mice and in congenic mice (Fig. 1).

$T X B_{2}, P G E_{2}$, and 6 keto $P G F_{1 \alpha}$ in $N Z B \times W$ mice. To eliminate the possibility that this increase in $\mathrm{TXB}_{2}$ synthesis was an idiosyncratic feature peculiar to the MRL-lpr strain, we evaluated renal cortical and medullary tissues at several time points in another strain of mice prone to nephritis (Fig. 2). Increased $\mathrm{TXB}_{2}$ synthesis occurred as mice aged from 2 to $4 \mathrm{mo}(P<0.01)$. An even greater increase in these mice was observed 4 mo later between 8 and 11 mo of age in both cortical and medullary tissue. In the NZB $\times W$ and MRL-lpr strain, the percentage incremental change in $\mathrm{TXB}_{2}$ was greater in the cortex. Before the onset of renal disease ( 2 mo of age), cortical and medullary $\mathrm{TXB}_{2}$ levels of the MRL-lpr and NZB $\times W$ mice were similar (Figs. 1 and 2). Although $\mathrm{TXB}_{2}$ increased in both strains, MRL-lpr mice developed a two- to threefold greater increase in intrarenal $\mathrm{TXB}_{2}$ with the development of renal disease as compared to $\mathrm{NZB} \times \mathrm{W}$ mice (Figs. 1 and 2). In sharp contrast to $\mathrm{TXB}_{2}$, renal $\mathrm{PGE}_{2}$ synthesis did not vary with age in the NZB $\times W$ mice. There was a substantial rise in 6 keto $\mathrm{PGF}_{1 \alpha}$ in the cortex between 2 and 4 mo (Fig. 2). However, this increase did not appear to be related to disease in that the kidneys of these mice were normal between 2 and 4 mo and there was no further increase in this eicosanoid between 4 and $11 \mathrm{mo}$, when renal disease developed.

\section{Glomerular preparations}

In glomerular enriched preparations, the level of $\mathrm{TXB}_{2}$ in MRLlpr mice at 4 mo of age was increased by a factor two to three times above values of age-matched congenic MRL -++ and two to three times above MRL-lpr mice at only 2 mo of age (Table I). There was no consistent trend in $\mathrm{PGE}_{2}$ synthesis in older MRL-lpr mice as compared with mice without lymphoproliferation. For example, in experiment 2 of Table II, $\mathrm{PGE}_{2}$ values (in $\mathrm{pg} / \mathrm{mg}$ of protein) were $33,768,36,726$, and 32,513 for MRLlpr mice at 2 and 4 mo and MRL -++ mice 4 mo of age, respectively.
Urinary protein and $T X B_{2}$

To determine whether there was a correlation between the amount of protein excreted and changes in $\mathrm{TXB}_{2}$ in $\mathrm{NZB} \times \mathrm{W}$ F1 hybrid mice, linear regression curves were constructed between urinary protein values and cortical $(a)$ or medullary $(b)$ $\mathrm{TXB}_{2}$ levels in mice of 2-11 mos of age (Fig. 3). Correlations were statistically shown for both cortical $\mathrm{TXB}_{2}$ levels with urinary proteins $(r=0.72, n=14, P<0.01)$ and medullary $\mathrm{TXB}_{2}$ levels with urinary protein $(r=0.74, n=12, P<.01)$. The correlation between an increase in protein excreted and intrarenal $\mathrm{TXB}_{2}$ was further substantiated using MRL-lpr mice of the same age but with varying amounts of urinary protein. There was a high degree of correlation in the cortex $(r=0.99, P<0.01)$ and medulla $(r=0.97, P<0.01)$ (Table II).

\section{Renal pathology}

MRL-lpr mice. The earliest features of renal disease in MRLlpr mice included proliferation of glomerular mesangial cells,

Table I. $T X B_{2}$ in Glomerular Enriched Preparations in MRL Mice

\begin{tabular}{llllc}
\hline Experiment & Strain & Age & $n$ & $\mathrm{TXB}_{2}$ \\
\hline \multirow{3}{*}{1} & & $m o$ & & $p g /$ mg of protein \\
& $l p r$ & 2 & 10 & 5,988 \\
& $l p r$ & 4 & 8 & 15,301 \\
& ++ & 4 & 8 & 5,421 \\
& & & & \\
& $l p r$ & 2 & 6 & 2,752 \\
& $l p r$ & 4 & 6 & 5,269 \\
& ++ & 4 & 6 & 2,246 \\
& $l p r$ & 2 & 10 & 3,800 \\
& $l p r$ & 4 & 10 & 8,511 \\
& ++ & 2 & 8 & 2,677 \\
& ++ & 4 & 8 & 3,219
\end{tabular}

$n$, number of kidneys pooled. 
Table II. Intrarenal $T X B_{2}$ and Urinary Protein in MRL-lpr Mice

\begin{tabular}{lll}
\hline $\mathrm{TXB}_{2}$ & & \\
\cline { 1 - 2 } Cortex & & \\
\hline$p g / m g$ of $t$ issue & Medullał & Urinary protein $\S$ \\
107 & $p g / m g$ of tissue & $m g / 24 \mathrm{~h}$ \\
60 & 206 & 4.4 \\
36 & 99 & 2.1 \\
19 & 62 & 1.7 \\
19 & 51 & 0.6 \\
& 41 & 0.6 \\
\hline
\end{tabular}

MRL-lpr mice were females 4-5 mo of age.

$* r=0.99, P<0.01$.

$\ddagger r=0.97, P<0.01$

$\S$ Amounts $>1.2$ are pathologic.

localization of immune complexes within the mesangial area, and an influx of mononuclear cells in the pelvic area (grade 1). As the disease progressed, there was a greater accumulation of cells and immune complexes in glomeruli (grade 2). Later, immune complexes localized in peripheral capillary loops, the glomerular basement membranes thickened, and there was a narrowing of capillary lumina and pronounced increase of cells within the mesangial area (grade 3). These glomerular changes were accompanied by a lymphocytic infiltration in the cortex and medulla (predominantly perivascular), and thickening of the intima and/or media of renal arteries. In the final stage of disease (grade 4), mononuclear cells, lymphocytes, macrophages, and plasma cells were in the cortical and medullary interstitium accompanied by tubular atrophy and casts, and crescent formation and sclerosis of glomeruli (Fig. $4 A$ and $B$ ). The time course of these renal changes began at 3 mo with mild proteinuria at 3-4 mos, and a $50 \%$ mortality between 5 and 6 mo of age.

$N Z B \times W$ mice. Renal disease in NZB $\times \mathrm{W}$ mice was a considerably slower illness than in the MRL-lpr mice. Glomerular changes were similar to those described for MRL-lpr mice; however, vasculitis was rare. Renal disease consisted of a modest

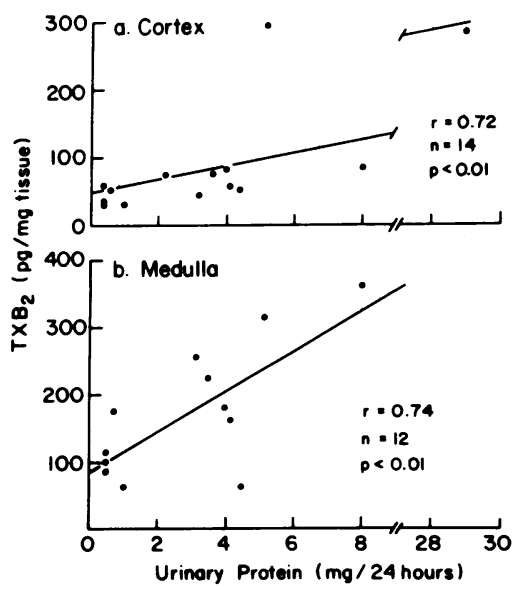

Figure 3. A linear regression analysis of $(a)$ cortical and $(b)$ medullary $\mathrm{TXB}_{2}$ vs. urinary protein in NZB $\times W$ female mice. Protein values $>1.2 \mathrm{mg} / 24 \mathrm{~h}$ are considered to be pathologic. increase in glomerular mesangial cells beginning at 4 mo of age, followed by immune complexes in the peripheral capillary walls and proteinuria at $6 \mathrm{mo}$, and a $50 \%$ mortality by 10 mo of age with only $10 \%$ surviving beyond $1 \mathrm{yr}$.

\section{Renal pathology and $T X B_{2}$}

$\mathrm{TXB}_{2}$ synthesis increased with the severity of renal pathology in autoimmune mice. A linear regression analysis plotting the degree of renal pathology in MRL-lpr mice vs. the level of cortical $\mathrm{TXB}_{2}$ showed a high degree of correlation $(r=0.87, n=22, P$ $<0.01$ ) between these variables (Fig. $5 a$ ). Similarly, TXB ${ }_{2}$ levels in the medulla of this strain also increased with the degree of renal pathology $(r=0.78, n=22, P<0.01)$ (Fig. $5 b$ ). A similar trend occurred in NZB $\times W$ mice. There was good correlation of an increase in $\mathrm{TXB}_{2}$ and the severity of pathology in the cortex $(r=0.80, n=9, P<0.01)$ and medulla $(r=0.82, n=9$, $P<0.01$ ) (Fig. 6).

\section{Treatments}

A series of treatment protocols was investigated to determine the relation between renal damage and $\mathrm{TXB}_{2}$ production.

Prostaglandin therapy with pharmacologic doses of PGE. In previous studies, twice-daily injections of pharmacologic doses of $\mathrm{PGE}_{1}$ or $\mathrm{PGE}_{2}$ protected MRL-lpr and $\mathrm{NZB} \times \mathrm{W}$ mice from developing renal disease $(16,21)$. As indicated in Table III, treatment of MRL-lpr mice with $\mathrm{PGE}_{1}$ modestly reduced $\mathrm{TXB}_{2}$ in the cortex but markedly suppressed production in the medulla as compared with the control group. Treated mice did not become proteinuric nor did they develop renal disease.

Blocking cyclooxygenase metabolites with ibuprofen. As previously reported by our laboratory, daily injections of ibuprofen $(8-9 \mathrm{mg} / \mathrm{kg})$ in NZB $\times W$ mice did not modify development of renal disease or survival (20). Although, as previously reported, this dose inhibits $90 \%$ of platelet $\mathrm{TXB}_{2}$ production (20), it did not alter the level of $\mathrm{TXB}_{2}$ in the kidney (Table IV). There was no substantial decrease in either $\mathrm{TXB}_{2}$ or $\mathrm{PGE}_{2}$ levels in the renal cortex or medulla in the $\mathrm{NZB} \times \mathrm{W}$ or MRL-lpr mice injected with this agent.

\section{Discussion}

The present experiments indicate that $(a)$ renal biosynthesis of the specific cyclooxygenase metabolite $\mathrm{TXB}_{2}$ increased in the MRL-lpr and NZB $\times W$ mice with spontaneous lupus nephritis; (b) as renal function deteriorated and renal pathologic events progressed, $\mathrm{TXB}_{2}$ increased in the renal medulla, cortex, and cortical glomeruli (60-90\% pure); (c) drug therapy and dietary manipulation that prevented renal disease correlated with no elevation in renal $\mathrm{TXB}_{2} ;(d)$ conversely, a dose of the cyclooxygenase inhibitor, ibuprofen, capable of decreasing platelet but not $\mathrm{TXB}_{2}$ intrarenal synthesis, did not prevent an increase in renal $\mathrm{TXB}_{2}$ or retard the progression of chronic renal injury. Together, these data indicate that increased intrarenal $\mathrm{TXB}_{2}$ synthesis accompanies renal disease in murine lupus nephritis.

Increased intrarenal $\mathrm{TXB}_{2}$ levels have been directly implicated in the relentless progression of immune-mediated and nonimmunologically induced forms of renal injury (4-8). The present study is the first report showing the increase of thromboxane in the progression of spontaneous, chronic renal disease in animal models with a human counterpart. Preliminary reports from other laboratories in several experimental rat models in- 

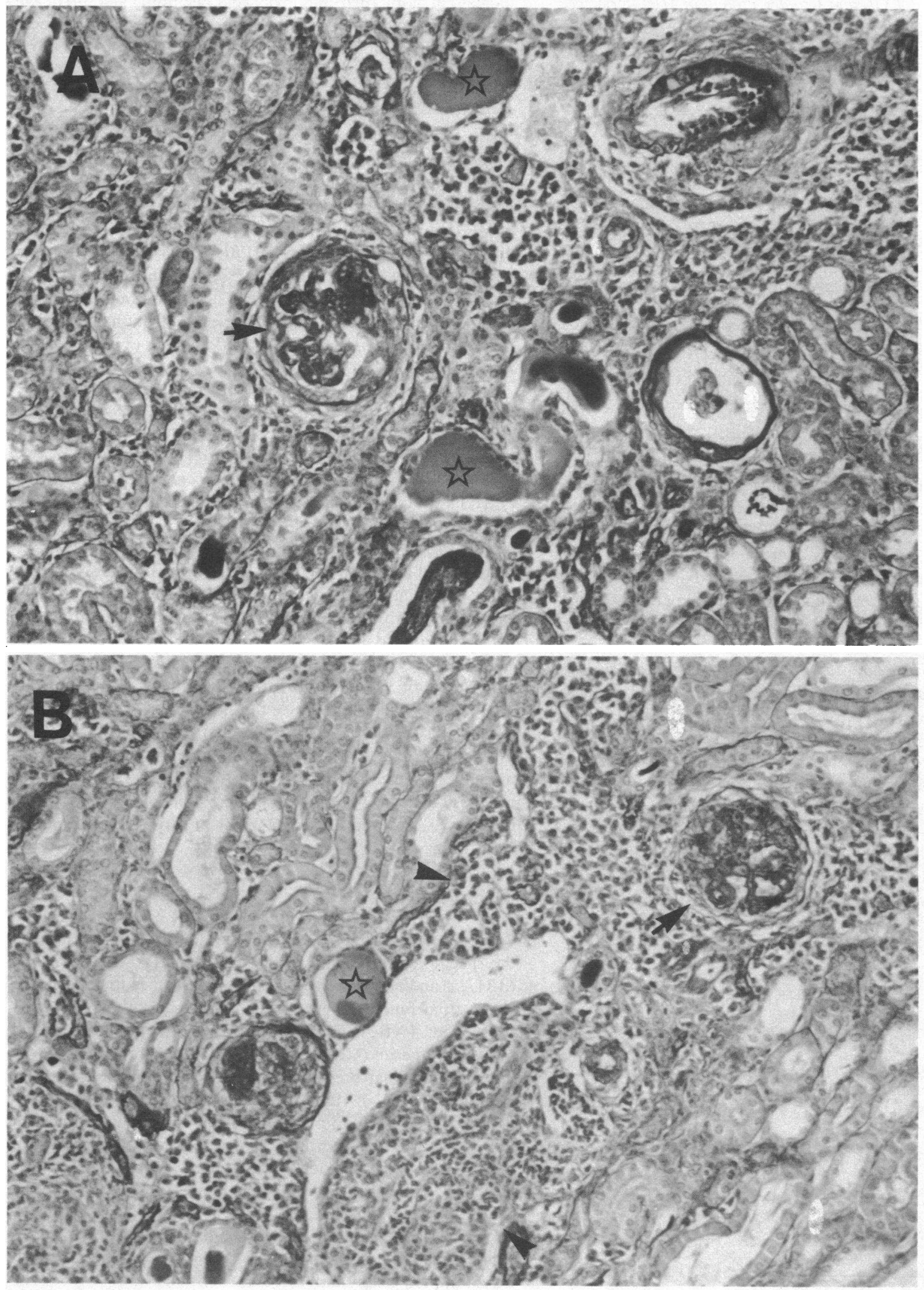

Figure 4. A paraffin section ( $a$ and $b$ ) of the cortex of the kidney of a female MRL-lpr mouse 6 mo of age scored as a grade 4. The prominent pathologic changes include sclerotic glomerulus (arrow), tubular casts $(\star)$, and a mononuclear cellular infiltrate (arrow head) in the interstitium and surrounding vessels. grade 0, normal and 4. most severe. Periodic acid-Schiff strain. 


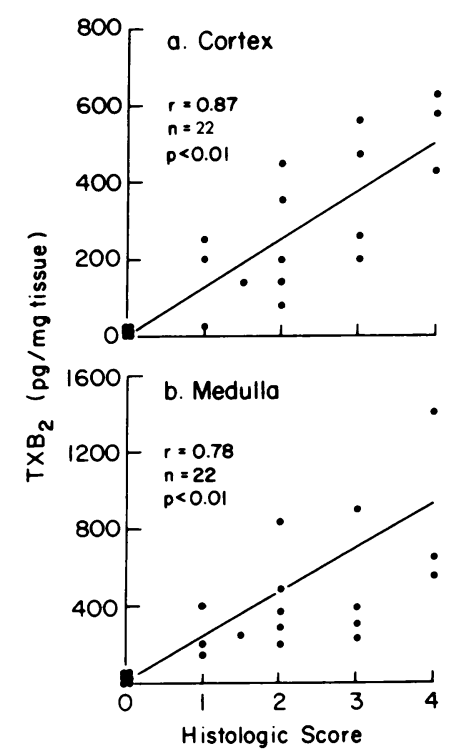

Table III. MRL-lpr Mice Treated with Pharmacologic Doses of 15-Methyl PGE

\begin{tabular}{cll}
\hline & \multicolumn{2}{l}{$\mathrm{TXB}_{2}$} \\
\cline { 2 - 3 } Treatment & Medulla & Cortex \\
\hline \multirow{2}{*}{$* \mathrm{PGE}_{1}$} & $p g / m g$ of tissue & $p g / m g$ of tissue \\
& $134 \pm 26 \ddagger$ & $73 \pm 12 \S$ \\
Control & $(4)$ & $(4)$ \\
& $262 \pm 19$ & $98 \pm 7$ \\
& $(4)$ & $(3)$
\end{tabular}

Figure 5. A linear regression analysis of the degree of renal MRL-lpr pathology vs. the amount of $\mathrm{TXB}_{2}$ synthesized in the renal $(a)$ cortex and $(b)$ medulla. Renal pathology was graded on a scale of $0-4$ with 0 , normal and 4, most severe pathologic changes.

dicate that augmentation of renal thromboxane biosynthesis is linked to the formation of proteinuria and/or impaired renal hemodynamics. For example, inhibiting renal thromboxane production prevents progressive renal disease with partial renal ablation (6), reduces proteinuria in adriamycin nephrosis (7), and prevents the decrements in the glomerular filtration rate in immunologically induced nephrotoxic serum nephritis (antiglomerular basement membrane disease) (4). Thus, it is apparent that intrarenal $\mathrm{TXA}_{2}$ levels can modulate renal hemodynamic forces and influence the course of renal damage.

What causes the intrarenal increase in thromboxane and which cells are producing this metabolite? Several candidates emerge as the cellular source responsible for increasing renal $\mathrm{TXB}_{2}$. Broadly, these cells could either be a component of the renal tissue, or alternatively, circulate into the kidney via the blood. Glomerular epithelial and mesangial cells, and collecting tubules are the intrinsic elements capable of synthesizing $\mathrm{TXB}_{2}$ (22-24). In murine lupus nephritis, there is an increase in mesangial cells, and a broadening of the glomerular epithelial foot

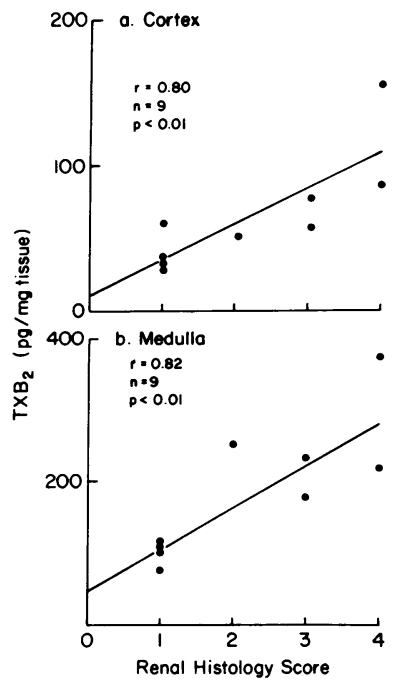

Figure 6. A linear regression analysis of the degree of pathology in $\mathrm{NZB} \times \mathrm{W}$ mice vs. the amount of $\mathrm{TXB}_{2}$ synthesized in the renal $(a)$ cortex and $(b)$ medulla. Renal pathology was graded on a scale of $0-$ 4 with 0 , normal and 4 , most severe pathologic changes.
Values are means \pm SEM.

* 15-methyl $\mathrm{PGE}_{1}$ injected bid for 2.5 mo.

$\ddagger P<0.01$.

$\S P<0.02$.

processes. In that these cell types are capable of synthesizing $\mathrm{TXB}_{2}$, intrarenal accumulation may be contributed to by these intrinsic renal components. However, because there is increased elaboration of $\mathrm{TXB}_{2}$ in the medulla, as well as the cortex, the glomerular changes cannot account exclusively for the total increase. This leaves the possibility of $\mathrm{TXB}_{2}$ release by circulating cells including leukocytes, monocytes, and platelets. Leukocytes can be eliminated because they are rarely present in kidneys of either MRL-lpr or NZB $\times W$ mice. Similarly, although platelets secrete abundant amounts of $\mathrm{TXB}_{2}$, it is unlikely that they are the source of increased intrarenal production because a dose of the cyclooxygenase inhibitor, ibuprofen, capable of blocking platelet $\mathrm{TXB}_{2}$ formation, did not reduce renal levels or protect autoimmune mice from renal injury. Thus, it is probable that monocytes, abundant in these kidneys and instrumental in the pathogenesis of glomerulonephritis, are a major source of eicosanoids (25-28).

Do patients with chronic renal disease have an increased level of $\mathrm{TXB}_{2}$ ? Elevated urinary $\mathrm{TXB}_{2}$ excretion $(29,30)$ has been connected with the deterioration of renal function in lupus patients with chronic glomerulonephritis (29) and during renal allograft rejection (30). Furthermore, recently, administration of dipyridamole and aspirin slowed the deterioration of renal function and the development of end-stage renal disease in

Table IV. Ibuprofen-treated Mice

\begin{tabular}{|c|c|c|c|c|}
\hline \multirow[b]{2}{*}{ Strain } & \multicolumn{2}{|l|}{$\mathrm{TXB}_{2}$} & \multicolumn{2}{|l|}{$\mathrm{PGE}_{2}$} \\
\hline & Medulla & Cortex & Medulla & Cortex \\
\hline & \multicolumn{2}{|c|}{$p g / m g$ of tissue } & \multicolumn{2}{|c|}{$\mathrm{pg} / \mathrm{mg}$ of tissue } \\
\hline \multicolumn{5}{|l|}{ MRL-lpr } \\
\hline Ibuprofen* & $340 \pm 64$ & $45 \pm 9$ & $1,673 \pm 242$ & $404 \pm 80$ \\
\hline Control & $362 \pm 65$ & $68 \pm 14$ & $2,092 \pm 118$ & $636 \pm 99$ \\
\hline \multicolumn{5}{|l|}{$\mathbf{N Z B} \times \mathbf{W}$} \\
\hline Ibuprofen* & $92 \pm 20$ & $23 \pm 4$ & $1,450 \pm 161$ & $363 \pm 66$ \\
\hline Control & $83 \pm 5$ & $23 \pm 2$ & $1,481 \pm 53$ & $424 \pm 120$ \\
\hline
\end{tabular}

Values are mean \pm SEM. $n=4$ at all points. MRL-lpr mice were 3 mo of age. NZB $\times W$ mice were 3 mo of age.

* Dose that inhibits platelet $\mathrm{TXB}_{2} 90 \%$ (20) 
membranoproliferative glomerulonephritis; a result that could be attributed to the inhibition of renal thromboxane (31). Thus, elevations in urinary $\mathrm{TXB}_{2}$ are prominent in several forms of renal injury.

Our results, combined with human studies and data from diverse experimental models of nephritis $(4,7,8)$ suggest that elevation of intrarenal $\mathrm{TXB}_{2}$ is a mediator of impaired renal function and a useful indicator of renal injury. To support the role of thromboxane as a modulator of renal injury, studies from our laboratory, as well as other investigators, showed that restricting substrate by feeding a diet deficient in an essential fatty acid (32) or by exclusively limiting lipid to fish oil $(9,10,33)$ prevented renal disease and increased survival in autoimmune mice. However, we cannot eliminate the possibility that this beneficial effect was promoted by a reduction in lipoxygenase metabolites. Because both diets reduced the amount of endogenous prostanoids (9) and are theoretically capable of also lowering the lipoxygenase metabolites (34), we cannot exclude the possibility that reductions in 12-hydroxy-5,8,11,13-eicosotetraenoic acid may influence the progression of renal injury. In fact, a recent study suggests that renal function is influenced by $\mathrm{TXA}_{2}$ as well as the sulfidopeptide leukotrienes (35). At the present time, it is uncertain whether the excess of $\mathrm{TXA}_{2}$ in lupus nephritis is a mediator of renal damage. Although treatment with pharmacologic doses of $\mathrm{PGE}_{1}$ prevents increases in renal $\mathrm{TXB}_{2}$ and renal injury, it is possible that the action of $\mathrm{PGE}_{1}$ is operating independently of $\mathrm{TXB}_{2}$ suppression. To clarify this point, studies in progress are investigating the effects of direct, specific in vivo inhibition of $\mathrm{TXA}_{2}$ synthesis in autoimmune mice. Thus, the hemodynamic, immunologic, and inflammatory consequences of altered renal cyclooxygenase metabolism should offer insight into the pathogenesis of renal injury and may provide promising therapeutic possibilities.

\section{Acknowledgments}

The expert technical assistance of Ben Rogall and Mary McPeak, secretarial skills of Ann Marie Bynoe, and critical review by Dr. Robert Lewis are greatly appreciated.

This work was supported by grant AM-30105 from the National Institutes of Health, the Pennsylvania Lupus Foundation, and the R. P. Scherer Corp. (Troy, MI).

\section{References}

1. Morley, J. 1981. Role of prostaglandins secreted by macrophages in the inflammatory process. In Lymphokines. Vol. 4. E. Pick, editor. Academic Press, Inc., New York. 377-391.

2. Lewis, G. P. 1983. Immunoregulatory activity of metabolites of arachidonic acid and their role in inflammation. Br. Med. Bull. 39:243248.

3. Dunn, M. J. 1983. Hormones and autocoids produced in the kidney. In Renal Prostaglandins. M. J. Dunn, editor. Williams \& Wilkins Co., Baltimore. 1-74.

4. Lianos, E. A., G. A. Andres, and M. J. Dunn. 1983. Glomerular prostaglandin and thromboxane synthesis in rat nephrotoxic serum nephritis. J. Clin. Invest. 72:1439-1448.

5. Okegawa, T., P. E. Jonas, K. DeSchryver, A. Kawasaki, and P. Needleman. 1983. Metabolic and cellular alterations underlying the exaggerated renal prostaglandin and thromboxane synthesis in ureter obstruction in rabbits. J. Clin. Invest. 71:81-90.

6. Purkeroon, M. L., J. H. Joist, A. Valdes, J. Yates, A. Morrison, and S. Klahr. 1985. Inhibition of thromboxane synthesis ameliorates the progressive kidney disease of rats with subtotal renal ablation. Proc. Natl. Acad. Sci. USA. 82:193-197.

7. Remuzzi, G., L. Imberti, M. Rossini, C. Morelli, C. Carmainati, G. M. Cattanco, and T. Bertani. 1985. Increased glomerular thromboxane synthesis as a possible cause of proteinuria in experimental nephrosis. J. Clin. Invest. 75:94-101.

8. Ichikawa, I., M. Purkeroon, J. Yateo, and S. Klahr. 1984. High protein diet augments renal vasoconstriction induced by bilateral uretheral obstruction (BUO). Kidney Int. 25:231. (Abstr.)

9. Kelley, V. E., A. Ferretti, S. Izui, and T. B. Strom. 1985. A fish oil diet rich in eicosapentenoic acid reduces cyclooxygenase metabolites and suppresses lupus in MRL-lpr mice. J. Immunol. 134:1914-1919.

10. Prickett, J. D., D. R. Robinson, and A. D. Steinberg. 1981. Dietary enrichment with the polyunsaturated fatty acid eicosapentenoic acid prevents proteinuria and prolongs survival in NZB $\times$ NZW F1 mice. $J$. Clin. Invest. 68:556-559.

11. Theofilopoulos, A. N., and F. J. Dixon. 1981. Etiopathogenesis of murine SLE. Immunol. Rev. 55:179-216.

12. Steinberg, A., D. P. Huston, J. D. Taurog, J. S. Cowdery, and E. S. Raveche. 1981. The cellular and genetic basis of murine lupus. Immunol. Rev. 55:121-154.

13. Zenser, T. V., and B. B. Davis. 1978. Effects of calcium on prostaglandin E2 synthesis by rat inner medullary slices. Am. J. Physiol. 235: F213-F218.

14. Burch, R. M., D. R. Knapp, and P. V. Halushka. 1979. Vasopressin stimulates thromboxane synthesis in the toad urinary bladder. Effects of imidazole. J. Pharmacol. Exp. Ther. 210:344-348.

15. Beck, T. R., A. Hassid, and M. J. Dunn. 1980. The effect of arginine vasopressin and its analogues on the synthesis of prostaglandin $\mathrm{E}_{2}$ by rat renal medullary interstitial cells in culture. J. Pharmacol. Exp. Ther. 215:15-19.

16. Kelley, V. E., A. Winkelstein, and S. Izui. 1979. Effect of prostaglandin $\mathrm{E}$ on immune complex nephritis in NZB/W mice. Lab. Invest. 41:531-537.

17. Kelley, V. E., and T. C. Cavallo. 1978. Urinary protein excretion in normal mice: variation with age and sex. Renal Physiol. 1:235-240.

18. Barcelli, U., R. Rademacher, Y. M. Ooi, and B. S. Ooi. 1981. Modification of glomerular immune complex deposition in mice by activation of the reticuloendothelial system. J. Clin. Invest. 67:20-27.

19. Lowry, O. H., N. J. Rosebrough, A. L. Farr, and R. J. Randall. 1951. Protein measurement with the Folin phenol reagent. J. Biol. Chem. 193:265-275.

20. Kelley, V. E., S. Izui, and P. V. Halushka. 1982. Effect of ibuprofen, a fatty acid cyclooxygenase inhibitor, on murine lupus. Clin. Immunol. Immunopathol. 25:223-231.

21. Kelley, V. E., A. Winkelstein, S. Izui, and F. J. Dixon. 1981. Prostaglandin $E_{1}$ inhibits $T$ cell proliferation and renal disease in MRLlpr mice. Clin. Immunol. Immunopathol. 21:190-203.

22. Hassid, A., M. Konieczkowski, and M. J. Dunn. 1979. Prostaglandin synthesis in isolated rat kidney glomeruli. Proc. Natl. Acad. Sci. USA. 76:1155-1159.

23. Petrulis, A. S., M. Aikawa, and M. J. Dunn. 1981. Prostaglandin and thromboxane synthesis by rat glomerular epithelial cells. Kidney Int. 20:469-474.

24. Scharschmidt, L., and M. J. Dunn. 1983. Prostaglandin synthesis by rat glomerular mesangial cells in culture. Effects of angiotensin II and arginine vasopressin. J. Clin. Invest. 71:1756-1764.

25. Hunsicker, L. G., T. P. Shearer, S. B. Plattner, and D. Weisenburger. 1979. The role of monocytes in serum sickness nephritis. J. Exp. Med. 150:413-425.

26. Holdsworth, S. R., N. M. Thomson, E. F. Glasgow, J. P. Dowling, and R. C. Atkins. 1978. Tissue culture of isolated glomeruli in experimental crescentic glomerulonephritis. J. Exp. Med. 147:98-109.

27. Striker, G. E., M. Mannick, and M. Y. Tung. 1979. Role of marrow-derived monocytes and mesangials cells in removal of immune complexes from renal glomeruli. J. Exp. Med. 149:127-136. 
28. Schreiner, G. F., J. M. Kiely, R. S. Cotran, and E. R. Unanue. 1981. Characterization of resident glomerular cells in the rat expressing Ia determinants and manifesting genetically restricted interactions with lymphocytes. J. Clin. Invest. 68:920-931.

29. Patrono, C., G. Ciabattoni, G. Remuzzi, E. Gotti, S. Bombardieri, O. Diamunno, and G. Tartarelli. The functional significance of prostacyclin and thromboxane $A_{2}$ production. J. Clin. Invest. 76:1011-1181.

30. Foegh, M. L., M. Zmudka, C. Cooley, J. F. Winchester, G. B Helfrich, P. W. Ramwell, and G. E. Schreiner. 1981. Urine i-TXB ${ }_{2}$ in renal allograft rejection. Lancet. ii:431-434.

31. Donadio, J. V., C. F. Anderson, J. C. Mitchell III, K. E. Holley, D. M. Ilstrup, V. Fuster, and J. H. Chesebro. 1984. Membranoproliferative glomerulonephritis. A prospective clinical trial of platelet-inhibitor therapy. N. Engl. J. Med. 310:1421-1426.
32. Hurd, E. R., J. M. Johnston, J. R. Okita, P. C. MacDonald, M. Ziff, and J. N. Gilliam. 1981. Prevention of glomerulonephritis and prolonged survival in New Zealand Black/New Zealand White F1 hybrid mice fed an essential fatty acid deficient diet. J. Clin. Invest. 67:476485.

33. Prickett, J. D., D. R. Robinson, and A. D. Steinberg. 1983. Effects of dietary enrichment with eicosapentenoic acid upon autoimmune nephritis in female NZB $\times N Z W / F 1$ mice. Arthritis Rheum. 26:133-139.

34. Prescott, S. M. 1984. The effect of eicosapentenoic acid on leukotriene B production by human neutrophils. J. Biol. Chem. 259:76157621.

35. Badr, K. F., V. E. Kelley, and B. M. Brenner. Selective antagonism of thromboxane $\mathrm{A}_{2}\left(\mathrm{TXA}_{2}\right)$ and sulfidopeptide leukotrienes (LTs) ameliorates endotoxin-induced renal ischemia. Kidney Int. 27:227. (Abstr.) 